\title{
Natural Establishment of Aspen from Seed on a Phosphate Mine Dump
}

\author{
BRYAN D. WILLIAMS AND ROBERT S. JOHNSTON
}

\begin{abstract}
The natural reproduction of aspen (Populus tremuloides Michx.) from seed was discovered on a phosphate mine dump in southeastern Idaho. Aspen seedlings were found growing on areas that were essentially bare except for scattered plantings of containerized shrubs and trees. Aspen survival and growth was monitored for 4 growing seasons. Seedling density varied from 2 to 10 per $\mathrm{m}^{2}$, seedling heights varied from 16 to $81 \mathrm{~cm}$, and survival rate was $73 \%$ at the end of $\mathbf{4}$ growing seasons. No changes in the number of seedlings were noted after the second growing season.
\end{abstract}

Aspen (Populus tremuloides Michx.) is a highly desirable, major component of the predisturbance vegetation on large areas of Western U.S. phosphate minelands. It is also desirable on mine waste spoils because it enhances plant species diversity, has recognized value for wild life habitat, watershed protection, and aesthetics.

Since the early 1970 's, most revegetation efforts have concentrated on grasses and forbs to stabilize the surface of mine dumps. However, once grasses and forbs are established, invasion by native shrubs and trees and survival of planted stock are greatly reduced due to shading and competition for water and nutrients (Williams, USFS, Logan, Utah, unpublished data). To avoid this competition, a mine dump was revegetated using 3 -m wide contour strips planted with containerized shrubs and trees, alternating with 10 -m strips that were fertilized and seeded with grasses and forbs (Fig. 1). The grass strips were seeded in the fall of 1978 and the

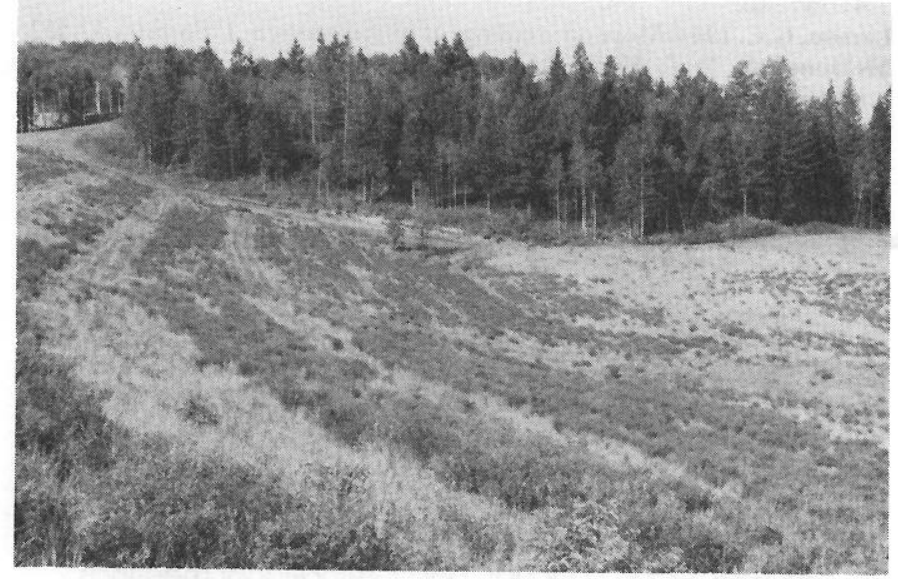

Fig. 1. General view of the mine dump showing the alternate strips of grass-forb and shrub-tree plantings.

containerized trees and shrubs were planted the following spring.

Quite unexpectedly in the fall of 1979 naturally regenerated aspen seedlings were discovered in the grass-free strips. Inspection of the roots of these seedlings by Dr. George A. Schier ${ }^{1}$ confirmed that the aspen originated from seed and not from sprouting of residual aspen roots. A seed source is located within $350 \mathrm{~m}$ upwind

\footnotetext{
Authors are research technican and research hydrologist, respectively, located at Intermountain Forest and Range Experiment Station, Forestry Sciences Laboratory,
Logan, Utah 84321 .

Manuscript accepted December 15, 1983.
}

IPlant physiologist, USDA, Forest Service, Forestry Sciences Laboratory, Delaware, $\mathrm{OH} 43015$. of the farthest seedlings. Seeds from this source were collected, germinated in the greenhouse and showed $96 \%$ germination.

The germination and establishment of aspen from seed is a rare occurrence over large areas of interior Western United States under the present climate of warm, dry summers. Discovery of the seedlings provided an opportunity to monitor survival and growth to determine if aspen can indeed become established naturally.

\section{Site Description}

The aspen seedlings are growing on a 3-ha north-facing phosphate mine spoil dump at an elevation of $2,100 \mathrm{~m}$, about $40 \mathrm{~km}$ northeast of Soda Springs, Ida. The average annual precipitation from 1977 to 1981 was $50 \mathrm{~cm}$, most of which was snow. Rainfall for June through September of 1979, the year the seedlings became established, was $7 \mathrm{~cm}$. The dump was constructed as a "head-ofvalley" fill with a $3: 1$ slope and a maximum depth of about $30 \mathrm{~m}$. The area was surfaced with a "mid-waste" shale, a highly weathered shale material located between alternating beds of phosphate ore. Numerous small water seeps are evident in the middle portion of the dump, where perched groundwater tables intersect the dump face. Most seep areas persist until mid-July and a few areas are wet through most of the growing season.

Aspen seedling distribution within the shrub strips is concentrated on, but is not limited to, these wet areas. While aspen appears throughout the shrub strips, no aspen seedlings have been found growing in the alternating grass strips.

\section{Methods}

In the fall of 1979,10 plots, each $1 \mathrm{~m}$ square, were established within four of the shrub strips. The plots were deliberately located so they contained aspen seedlings. Five plots were located on wet areas near water seeps and 5 on drier areas away from any visible signs of surface water. The design served as a means of monitoring survival and growth of the aspen and was not intended to provide any other statistical inference.

The number and height of seedlings on each plot was recorded at the end of each growing season for 4 years.

\section{Results}

The number of aspen seedlings on all plots declined from 73 in 1979 to 53 at the end of the 1982 growing season. This is a $73 \%$ survival over that 3 years. Seedling losses occurred between the second and third growing season (Fig. 2). Seedling numbers remained constant during the third and fourth year. The initial number of seedlings was slightly higher on the wet sites than on the drier sites and this general relationship persisted. The range of seedling numbers on all individual plots varied from 2 to 10 per plot with a slightly narrower range on wetter plots than on drier ones.

Plant height was slightly greater on the wet areas than on dry areas (Fig. 3). The growth rate on the wet sites was markedly greater during the 1980 growing season and declined the next year. Except for this 1 year, the rate of growth was about the same for both areas.

The average height of seedlings after 1 growing season was $1.4 \pm$ $.36 \mathrm{~cm}$. At the end of the fourth season the average height was $38 \pm$ 


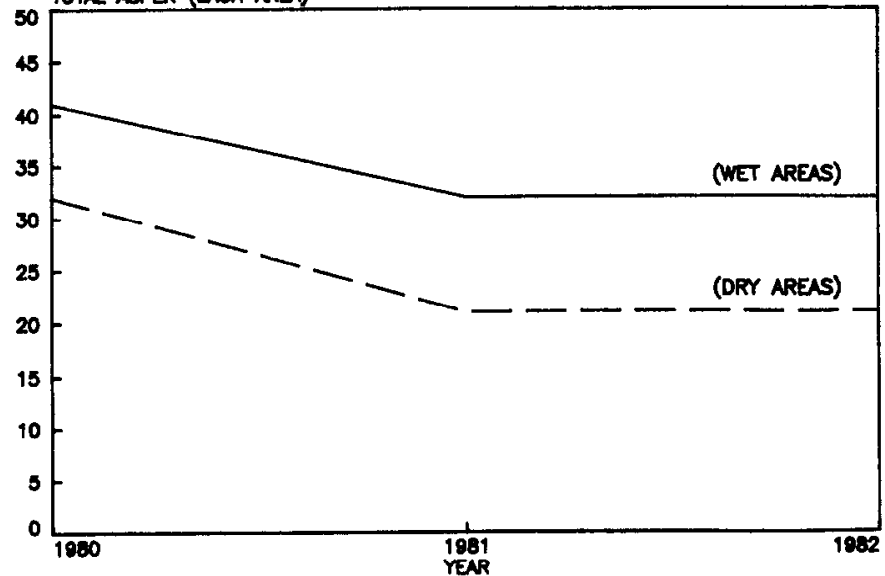

Fig. 2. Aspen seedling survival.

$15 \mathrm{~cm}$. The range in height was $16 \mathrm{~cm}$ to $81 \mathrm{~cm}$. The mean height of aspen on the wetter sites was $14 \mathrm{~cm}$ greater than on the dry sites at the end of 4 seasons. In the fall of 1982 the height of 60 additional seedlings growing throughout the shrub strips was measured. Average height was $35 \pm 19 \mathrm{~cm}$. These heights are similar to the heights of seedlings within the sample plots.

\section{Discussion}

Although most reproduction of western aspen is achieved by vegetative sprouting, aspen can occasionally become established under favorable seedbed and climatic conditions (Ellison 1943, Larson 1944, Barnes 1966). Aspen are prolific seed producers and seeds germinate rapidly under a wide temperature range. The main deterrents to aspen reproduction from seed are the rigorous requirements of friable mineral soil, limited competition, and a continuous supply of soil water (Barnes 1966, McDonough 1979).

Areas within the bare strips in or near ground water seeps fulfill these requirements. No aspen seedlings were found in the adjacent
AVERACE HECHT (CENTMETERS)

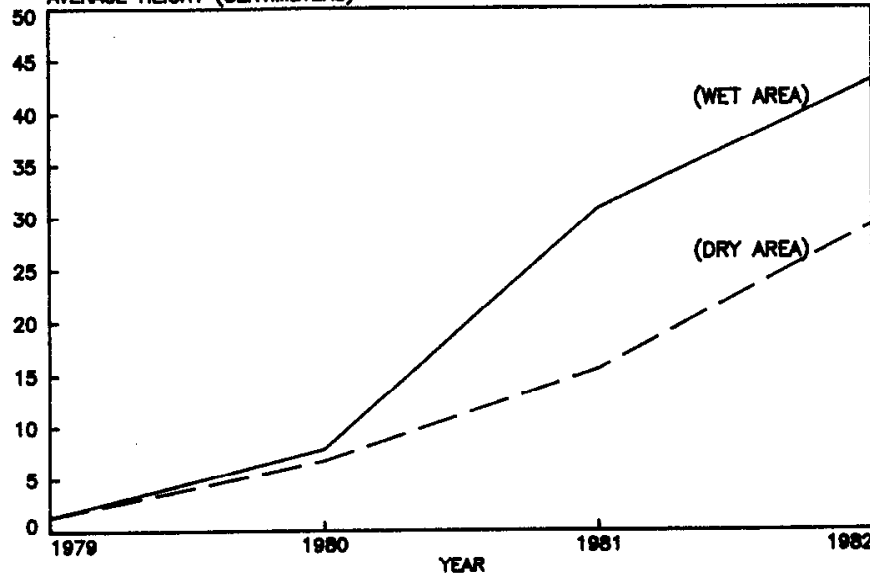

Fig. 3. Aspen growth rate (average of 5 plots each area).

grass strips regardless of observed surface moisture conditions.

Our observations, while not conclusive, indicate that aspen can be established on selected phosphate mine dumps from seed. Since this manuscript was written another phosphate mine dump has been discovered where aspen are growing from seed. The natural establishment of aspen on mine sites eliminates costly propagation and planting of containerized trees. An additional advantage may be realized because the introduction of a large gene pool through natural seeding increases the probability of site adaptability and survival.

\section{Literature Cited}

Barnes, B.V. 1966. The clonal growth habit of American aspens. Ecology 47:439-447.

Ellison, L. 1943. A natural seedling of western aspen. J. Forestry. 41:767-768.

Larson, G.C. 1944. More on seedlings of western aspen. J. Forestry 42:452.

McDonough, W.T. 1979. Quaking aspen-seed germination and early seedling growth. USDA, Forest Serv., Res. Pap. INT-234.

\section{Membership in the Society for Range Management. . .}

is open to those engoged in or interested in the study. management. or use of range ecosystems and the intelligent use of all range resources

includes research scientists, ranchers, governmental agency administrators and technical personnel. teachers, students, and people from the business community

provides members with two publications - one oriented to research (Journal of Range Management) and the other oriented to practical resource manogement (Rangelands) offers opportunities for foce-to-face exchange of ideas at local, national, and intemational meetings of the Society.

Dues vary according to type of membership and geagraphical section. For application forms and additional information, contact the:

Society for Range Manogement

2700 West Fitth Avenue

Denver, Colorodo 80204

(303) 571-0174 